\title{
ETYCZNE ASPEKTY FUNKCJONOWANIA SEKTORA UBEZPIECZEŃ WOBEC ZMIAN KLIMATYCZNYCH I EKSTREMALNYCH ZJAWISK POGODOWYCH
}

\begin{abstract}
Streszczenie: Obserwowana zmiana klimatu i zwiazane z niq ekstremalne zjawiska pogodowe sq przyczyna rosnących strat społecznych $i$ gospodarczych na świecie. Stanowia również wyzwanie dla sektora ubezpieczeniowego, który szacuje, że około 75\% katastrof naturalnych o catkowitej wartości około $100 \mathrm{mld}$ USD rocznie jest zwiazanych ze zjawiskami hydrometeorologicznymi.

Celem rozdziału jest omówienie głównych problemów funkcjonowania sektora ubezpieczeniowego zwiazanych ze wzrostem ryzyka katastrof naturalnych, identyfikacja nowych wyzwań, przed jakimi stoi ten sektor oraz zwiazanych z nimi kwestii etycznych. Najważniejsze etyczne wyzwania stanowia: wykluczenie niektórych osób $i$ calych grup społecznych z systemu ubezpieczeniowego, brak możliwości ubezpieczenia na niektórych obszarach z powodu wzrostu ryzyka i etos efektywności. Próba budowy mostu pomiędzy etyka a ekonomiq w odniesieniu do sektora ubezpieczeń napotyka na poważne przeszkody zwiazane z trudnościami w kalkulacji ryzyka z jednej strony i jego pieniężna wycena z drugiej. Kwestie etyczne pozostają na marginesie wspótczesnej dyskusji na temat funkcjonowania systemu ubezpieczeń od ryzyk klimatycznych i pogodowych.
\end{abstract}

Słowa kluczowe: etyka, sektor ubezpieczeń, zmiana klimatu, ekstremalne zjawiska pogodowe.

\section{WSTĘP}

Obserwowane w ostatnich latach nasilenie się występowania ekstremalnych zjawisk pogodowych takich jak huragany, burze tropikalne, deszcze nawalne, gradobicia, fale gorąca i fale mrozów, burze śnieżne, susze i powodzie, a także często związanych z nimi zdarzeń takich jak pożary lasów i osunięcia się ziemi, niebezpodstawnie kojarzone są ze zmianami klimatu. Pomimo braku pełnej zgodności poglądów co do antropogenicznego pochodzenia globalnego ocieplenia, podmioty gospodarcze i społeczeństwa muszą coraz częściej stawić czoła konsekwencjom obserwowanych zjawisk i zmianom jakie zachodzą w miejscu ich życia i gospodarowania. Adaptacja do zmian klimatu obok działań infrastrukturalnych i organizacyjnych obejmuje także rozwój odpowiednich systemów przenoszenia ryzyka pogodowego.

Wycena i handel ryzykiem jest jedną z funkcji pełnionych przez globalny system finansowy. W odniesieniu do ryzyka pogodowego istnieją dwa sposoby

\footnotetext{
* Prof. UŁ dr hab. Małgorzata Burchard-Dziubińska, Wydział Ekonomiczno-Socjologiczny, Uniwersytet Łódzki.
} 
jego przenoszenia - ubezpieczenia i instrumenty pochodne, zwane derywatami pogodowymi. W niniejszym rozdziale zajmiemy się wyłącznie sektorem ubezpieczeń. Celem rozważań jest identyfikacja wyzwań, przed jakimi stoi sektor ubezpieczeń w związku ze wzrostem ryzyka wynikającego z występowania ekstremalnych zjawisk pogodowych oraz etyczne kwestie jego funkcjonowania.

Szacuje się, że od lat 1980. kwota odszkodowań wypłacanych z powodu katastrof wywołanych przez zjawiska pogodowe podwaja się co dekadę (z uwzględnieniem inflacji) ${ }^{1}$. Nawet biorąc pod uwagę, że wyniki badań naukowych dotyczące przyszłych zmian klimatu są obarczone dużym stopniem niepewności, nie należy zupełnie ignorować możliwości sprawdzenia się niekorzystnych scenariuszy. Ocenia się, że około 3/4 katastrof naturalnych jest związane ze zjawiskami hydrometeorologicznymi. Przyrost liczby ludności narażonej na występowanie groźnych w skutkach zjawisk pogodowych wymusza tworzenie strategii zarządzania ryzykiem katastroficznym. Zagrożenia dotyczą zarówno zdrowia i życia ludzi, jak i stanu infrastruktury i majątku różnych podmiotów gospodarczych (przedsiębiorstw, gospodarstw domowych, podmiotów komunalnych) oraz możliwości inwestowania i prowadzenia działalności gospodarczej.

Na podstawie raportów Światowej Organizacji Zdrowia (WHO), Światowej Organizacji Meteorologicznej (WMO) oraz danych statystycznych publikowanych przez Munich Re dotyczących pochodzenia katastrof naturalnych na świecie, a zwłaszcza tych zdarzeń, które były efektem wystąpienia ekstremalnych zjawisk pogodowych, podjęta zostanie próba identyfikacji wyzwań etycznych, wobec których stoi sektor ubezpieczeniowy.

\section{PRZEJAWY ZMIANY KLIMATU}

Obserwowane od szeregu lat ocieplanie się klimatu jest przedmiotem ciągłych badań, a także dyskusji politycznych dotyczących z jednej strony podjęcia współpracy na rzecz ochrony klimatu, a z drugiej rozwoju działań adaptacyjnych. Wynika to $\mathrm{z}$ faktu, że klimat jest jednym z najistotniejszych czynników determinujących funkcjonowanie społeczeństw i gospodarek, a jego zmiana w różnym stopniu dotknie ziemskie ekosystemy, wpływając na możliwości gospodarowania na wielu obszarach. Klimat jest zjawiskiem złożonym, najczęściej definiowanym jako całokształt stanów pogody właściwych dla danego obszaru wraz z przeciętnym przebiegiem rocznego rytmu ich zmian w dłuższym okresie. Pod wpływem obserwacji różnych zjawisk i obiektów w klimatologii zaczyna obowiązywać paradygmat „zmiennego klimatu”2. Na kształtowanie się klimatu

${ }^{1}$ E. Mills, The Greening of Insurance, „Science”, 14 December 2012, vol. 338(1425), www.sciencemag.org [dostęp: 15.11.2015].

${ }^{2}$ Botkin i in., Oblicza ziemi - zagrożenia i nadzieje, Raport The Smithonian Institution i National Geographic, 2001. 
mają wpływ liczne czynniki. Są to zjawiska zachodzące w atmosferze ziemskiej związane z promieniowaniem słonecznym, bilansem energetycznym, obiegiem wody i cyrkulacją powietrza oraz czynniki geograficzne takie jak: szerokość geograficzna, wysokość nad poziomem morza, rzeźba terenu, charakter podłoża. System klimatyczny obejmuje bowiem całość atmosfery, hydrosfery, biosfery i geosfery i ich wzajemne oddziaływanie. Nie ulega wątpliwości, że obecnie coraz bardziej intensywnie na te sfery oddziałuje także człowiek ${ }^{3}$. Międzyrządowy Zespół do Spraw Zmian Klimatu (Intergovermental Panel on Climate Change - IPCC) uznał, że zmiana klimatu ,jest to proces dotyczący jakichkolwiek zmian klimatu w czasie związanych zarówno ze zmianami naturalnymi, jak i będącymi wynikiem działań człowieka"4.

Ze względu na złożoność ziemskiego ekosystemu i mnogość czynników wpływających na klimat trudno precyzyjnie przewidzieć skutki zmian. Naukowcy są jednak zgodni, że w przypadku globalnego ocieplenia nastąpi:

- podniesienie poziomu wód mórz i oceanów wskutek zwiększania się objętości wody (ekspansja termiczna) i zwiększania się ilości wody przez topnienie lodowców i lądolodów,

- zmiana stosunków wodnych i warunków upraw rolnych,

- przyspieszenie topnienia lodowców i lądolodów,

- przesuwanie się stref klimatycznych i stref upraw,

- częstsze występowanie katastrof i ekstremalnych zjawisk pogodowych, pojawianie się częstych anomalii pogodowych (takich jak: grad, huragan, deszcze nawalne, długie okresy suszy),

- zmiana rozkładu opadów oraz ich intensywności,

- pustynnienie wielu obszarów,

- wymieranie niektórych zwierząt i roślin,

- zmniejszenie się zasobów wody pitnej ${ }^{5}$.

Wszystkie wymienione konsekwencje zmian klimatu pociągną za sobą wielorakie skutki dla ludności i gospodarek poszczególnych państw. Ich charakter i skala będą wypadkową oddziaływania zmian klimatu, ekstremalnych zjawisk pogodowych oraz wrażliwości, podatności i adaptacyjności systemów przyrodniczych i społeczno-gospodarczych na ich wpływ ${ }^{6}$.

${ }^{3} \mathrm{~J}$. Wybig, Współczesne zmiany klimatyczne - przesłanki wpływu czynników antropogenicznych, Katedra Meteorologii i Klimatologii Uniwersytetu Łódzkiego, Łódź 2008.

${ }^{4}$ http://www.ipcc.ch/.

${ }^{5}$ S. Liszka, S. Pasierb, Energetyka a zmiany klimatu, Instytut na rzecz Ekorozwoju, Warszawa 2008 , s. $10-12$

${ }^{6}$ M. Burchard-Dziubińska, Instytucjonalne aspekty międzynarodowej wspótpracy $w$ dziedzinie ochrony środowiska przyrodniczego, Wydawnictwo Uniwersytetu Łódzkiego, Łódź 2006, s. $199-204$. 


\section{GOSPODARCZE I SPOLECZNE KONSEKWENCJE ZMIAN KLIMATYCZNYCH}

Wpływ zmiany klimatu na poszczególne obszary jest i będzie bardzo zróżnicowany ze względu na łączne oddziaływanie czynników przyrodniczych i tych związanych z poziomem rozwoju i organizacji społeczeństw i gospodarek. Generalnie społeczności w regionach słabo rozwiniętych pod względem gospodarczym są bardziej podatne na negatywne oddziaływania, a ich możliwości adaptacyjne oceniane są jako niskie ze względu na brak zasobów finansowych i technicznych. Podatność na negatywne czynniki jest znaczna ze względu na ubóstwo, uzależnienie rolnictwa od opadów deszczu i częste susze lub powodzie. Powoduje to zagrożenie obniżeniem plonów zbóż, a to zagraża bezpieczeństwu żywnościowemu. Dotyczy to w pierwszej kolejności ubogich krajów Afryki, Azji i Ameryki Łacińskiej. Ich mieszkańcy właściwie pozostają bezbronni wobec ekstremalnych zjawisk pogodowych ze względu na brak technicznych środków przestrzegania i ochrony przed atakami żywiołów. Brak odpowiednich systemów ubezpieczeń dodatkowo utrudnia przezwyciężenie negatywnych konsekwencji katastrof naturalnych. Regiony wysoko rozwinięte generalnie wykazują znacznie niższą podatność na zmiany klimatu i wyższą adaptacyjność do nowych warunków wynikającą zarówno z możliwości finansowych, jak i technicznych. Jednak nawet w krajach wysoko rozwiniętych konsekwencje długotrwałych susz i coraz bardziej ograniczonego dostępu do wody zaczynają stanowić poważny problem rozwojowy i wyzwanie dla sektora ubezpieczeń. W ostatnich latach poważne problemy związane z niedostatkiem wody mają: Australia, Hiszpania, Włochy, Grecja, Stany Zjednoczone - głównie stan Kalifornia. W przypadku Kalifornii powstała nawet specjalna strona internetowa, na której prowadzony jest monitoring trwającej już od czterech lat suszy ${ }^{7}$.

Ryzyko związane z klęskami żywiołowymi i klimatem ma znaczny wpływ na gospodarkę, a także na bezpieczeństwo i dobrostan obywateli. $Z$ uwagi na fakt, że w ostatnich latach narażenie na klęski żywiołowe znacznie wzrosło z powodu łącznego oddziaływania zmiany klimatu, presji demograficznej, gwałtownej i nieplanowanej urbanizacji, bardziej intensywnego użytkowania gruntów na zagrożonych obszarach, wprowadzania nowych elementów infrastruktury technicznej, a także degradacji ekosystemów, konieczne jest prowadzenie dalszych obserwacji i badań, które pozwolą opracować metody ograniczania ryzyka i adaptacji do nowych warunków. Wyniki tych badań są istotne z punktu widzenia możliwości kształtowania polityki rozwoju na danym obszarze. Mają także znaczenie dla sektora ubezpieczeniowego, który musi skonfrontować się $\mathrm{z}$ nową rzeczywistością w zakresie występowania ryzyka pogodowego ${ }^{8}$.

\footnotetext{
${ }^{7} \mathrm{http}: / /$ www.cadrought.com/drought-monitor/.

${ }^{8}$ Plan działania z Hyogo na lata po 2015 r.: Zarzadzanie ryzykiem $w$ celu budowania odporności, Komunikat Komisji dla Parlamentu Europejskiego, Rady Europejskiego Komitetu Ekonomicznego i Społecznego i Komitetu Regionów, Bruksela, 8 kwiecień 2014, COM (2014) 0216 final.
} 
W jednym $\mathrm{z}$ najnowszych raportów będących efektem konferencji zorganizowanej przez WHO w 2014 r. stwierdzono między innymi, że do połowy bieżącego stulecia można się spodziewać dodatkowych 250000 zgonów rocznie wywołanych przez czynniki klimatyczne. Cytowany w tym raporcie Międzyrządowy Zespół ds. Zmian Klimatu (IPCC) ocenia, że istnieją mocne dowody na wystąpienienie zwiększonego ryzyka urazów, zachorowań i zgonów $\mathrm{z}$ następujących powodów:

- udarów, zawałów serca i odwodnienia w okresach fal gorąca i pożarów,

- chorób przenoszonych drogą pokarmową z powodu braku dostępu do czystej wody,

- chorób przenoszonych przez wektory,

- niedożywienia wynikajacego ze zmniejszonej produkcji żywności w regionach biednych, często dotkniętych przez susze lub powodzie.

W raporcie zwraca się także uwagę na możliwość wystąpienia konfliktów zbrojnych związanych z niedoborem niektórych zasobów, masowe przemieszczanie się ludności z terenów narażonych na zalanie (wybrzeża i estuaria rzek, małe państwa wyspiarskie) $)^{9}$. Zasobem o kluczowym znaczeniu jest woda ${ }^{10}$.

\section{KATASTROFICZNE RYZYKO POGODOWE W ŚWIETLE DANYCH STATYSTYCZNYCH}

Do ogólnej charakterystyki obserwowanych na świecie ekstremalnych zjawisk pogodowych i związanych z nimi ryzyk i konsekwencji społecznych, gospodarczych i dla sektora ubezpieczeń wykorzystane zostaną dane udostępnione przez Munich $\mathrm{Re}^{11}$. Munich Re (Münchener Rückversicherungs-Gesellschaft Aktiengesellschaft in München) jest obecnie największym na świecie reasekuratorem grupy Ergo. Od 1880 r. grupa ta specjalizuje się w ocenie ryzyka. Jej klientami są w pierwszej kolejności przedsiębiorstwa ubezpieczeniowe - blisko 6 tysięcy podmiotów w 150 krajach.

Na rynku ubezpieczeń rozróżnia się klęski żywiołowe i katastrofy naturalne. Klęska żywiołowa zwana też kataklizmem jest to ekstremalne zjawisko naturalne powodujące znaczne szkody na terenie objętym tym zjawiskiem, pozostawiające po sobie często zmieniony obraz powierzchni ziemi. Do klęsk żywiołowych zaliczamy:

${ }^{9}$ Conference Report, Conference on Health and Climate Change, Word Health Organization, 27-29 August 2014, Geneva Switzerland, s. 6-7, http://www.who.int/globalchange/media-centre/ events/climate-health-conference/whoconference-onhealthandclimatechangefinalreport.pdf [dostęp: 12.11.2015].

${ }^{10}$ F. Sultana, A. Loftus, Prawo do wody w perspektywie politycznej, gospodarczej i spolecznej, PAH, Warszawa 2012.

${ }^{11} \mathrm{http} / / /$ www.munichre.com/touch/portal/en/homepage/default-engineering/index.html. 
- powodzie,

- susze,

- rozległe pożary terenu,

- trzęsienia ziemi,

- wybuchy wulkanów,

- tsunami,

- huragany i tornada,

- obfite opady śniegu oraz lawiny śnieżne,

- ekstremalne upały lub mrozy, szczególnie w dłuższym okresie,

- osuwiska ziemi,

- katastrofy kosmiczne - upadek meteorytu, eksplozja meteoru, wybuch bliskiej supernowej.

Pojęcie klęski żywiołowej w znacznie większym stopniu odnosi się do wpływu, jaki ona wywiera na człowieka niż na przyrodę. $Z$ punktu widzenia towarzystw ubezpieczeniowych ważne jest to, że klęski żywiołowe pociągają za sobą znaczne straty materialne, a także stanowią poważne zagrożenie dla zdrowia i życia ludzi.

Często pojęcie klęski żywiołowej stosuje się zamiennie z pojęciem katastrofy naturalnej. Warto jednak wspomnieć, że w polskim ustawodawstwie są te pojęcia definiowane odrębnie. I tak w art. 3. 1. ustawy o stanie klęski żywiołowej ilekroć w ustawie jest mowa o:

1) klęsce żywiołowej - to rozumie się przez to katastrofę naturalną lub awarię techniczną, których skutki zagrażają życiu lub zdrowiu dużej liczby osób, mieniu w wielkich rozmiarach albo środowisku na znacznych obszarach, a pomoc i ochrona mogą być skutecznie podjęte tylko przy zastosowaniu nadzwyczajnych środków, we współdziałaniu różnych organów i instytucji oraz specjalistycznych służb i formacji działających pod jednolitym kierownictwem,

2) katastrofie naturalnej - to rozumie się przez to zdarzenie związane z działaniem sił natury, w szczególności wyładowania atmosferyczne, wstrząsy sejsmiczne, silne wiatry, intensywne opady atmosferyczne, długotrwałe występowanie ekstremalnych temperatur, osuwiska ziemi, pożary, susze, powodzie, zjawiska lodowe na rzekach i morzu oraz jeziorach i zbiornikach wodnych, masowe występowanie szkodników, chorób roślin lub zwierząt albo chorób zakaźnych ludzi albo też działanie innego żywiołu ${ }^{12}$.

W danych publikowanych przez Munich Re rozróżnia się:

- zdarzenia geofizyczne - obejmujące trzęsienia ziemi, tsunami i aktywność wulkaniczną,

- zdarzenia meteorologiczne - obejmujące różnego rodzaju burze (tropikalne, konwekcyjne, ekstra tropikalne i lokalne),

${ }^{12}$ Ustawa z 18 czerwca 2002 r. o stanie klęski żywiołowej, DzU 2002, nr 62, poz. 558. 
- zdarzenia hydrologiczne - obejmujące powodzie i osunięcia ziemi,

- zdarzenia klimatyczne - obejmujące ekstremalne temperatury, susze i pożary lasów.

W tab. 1 znajdują się dane z lata 2010-2014 dotyczące naturalnych zdarzeń katastroficznych z podziałem na cztery kategorie: zdarzenia ogółem, liczba ofiar śmiertelnych, wartość strat ogółem, wartość strat ubezpieczonych.

Tabela 1. Katastrofy naturalne na świecie w latach 2010-2014

\begin{tabular}{|c|c|c|c|c|c|c|}
\hline & & 2010 & 2011 & 2012 & 2013 & 2014 \\
\hline \multirow{5}{*}{ 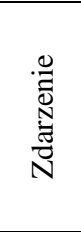 } & liczba ogółem & 960 & 820 & 905 & 890 & 980 \\
\hline & z. geofizyczne & $9 \%$ & $9 \%$ & $7 \%$ & $10 \%$ & $8 \%$ \\
\hline & z. meteorologiczne & $40 \%$ & $37 \%$ & $45 \%$ & $44 \%$ & $41 \%$ \\
\hline & z. klimatyczne & $12 \%$ & $17 \%$ & $12 \%$ & $9 \%$ & $9 \%$ \\
\hline & z. hydrologiczne & $39 \%$ & $37 \%$ & $36 \%$ & $37 \%$ & $42 \%$ \\
\hline \multirow{5}{*}{ 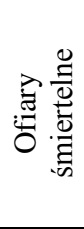 } & liczba ogółem & 295000 & 27000 & 9600 & 20500 & 7700 \\
\hline & z. geofizyczne & $77 \%$ & $62 \%$ & $7 \%$ & $5 \%$ & $11 \%$ \\
\hline & z. meteorologiczne & $1 \%$ & $11 \%$ & $27 \%$ & $38 \%$ & $17 \%$ \\
\hline & z. klimatyczne & $19 \%$ & $2 \%$ & $18 \%$ & $8 \%$ & $6 \%$ \\
\hline & z. hydrologiczne & $3 \%$ & $25 \%$ & $48 \%$ & $49 \%$ & $66 \%$ \\
\hline \multirow{5}{*}{ 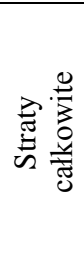 } & ogółem & $\begin{array}{l}150 \mathrm{mld} \\
\text { USD }\end{array}$ & $\begin{array}{l}380 \mathrm{mld} \\
\text { USD }\end{array}$ & $\begin{array}{l}170 \mathrm{mld} \\
\text { USD }\end{array}$ & $\begin{array}{l}135 \mathrm{mld} \\
\text { USD }\end{array}$ & $\begin{array}{c}110 \mathrm{mld} \\
\text { USD }\end{array}$ \\
\hline & z. geofizyczne & $34 \%$ & $61 \%$ & $12 \%$ & $7 \%$ & $7 \%$ \\
\hline & z. meteorologiczne & $29 \%$ & $19 \%$ & $59 \%$ & $49 \%$ & $46 \%$ \\
\hline & z. klimatyczne & $5 \%$ & $3 \%$ & $16 \%$ & $7 \%$ & $20 \%$ \\
\hline & z. hydrologiczne & $32 \%$ & $17 \%$ & $13 \%$ & $37 \%$ & $27 \%$ \\
\hline \multirow{6}{*}{ 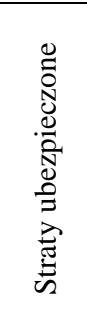 } & ogółem & $\begin{array}{l}38 \mathrm{mld} \\
\text { USD }\end{array}$ & $\begin{array}{c}105 \mathrm{mld} \\
\text { USD } \\
\end{array}$ & $\begin{array}{l}70 \mathrm{mld} \\
\text { USD }\end{array}$ & $\begin{array}{l}35 \mathrm{mld} \\
\text { USD }\end{array}$ & $\begin{array}{c}31 \mathrm{mld} \\
\text { USD }\end{array}$ \\
\hline & $\begin{array}{l}\text { jako procent strat } \\
\text { całkowitych }\end{array}$ & 25,3 & 27,6 & 41,1 & 25,9 & 28,1 \\
\hline & z. geofizyczne & $35 \%$ & $47 \%$ & $3 \%$ & $<1 \%$ & $2 \%$ \\
\hline & z. meteorologiczne & $52 \%$ & $37 \%$ & $68 \%$ & $71 \%$ & $69 \%$ \\
\hline & z. klimatyczne & $4 \%$ & $3 \%$ & $28 \%$ & $2 \%$ & $18 \%$ \\
\hline & z. hydrologiczne & $9 \%$ & $13 \%$ & $1 \%$ & $27 \%$ & $11 \%$ \\
\hline
\end{tabular}

Źródło: opracowanie własne na podstawie https://www.munichre.com/touch/natural-hazards/ en/natcatservice/annual-statistics/index.html [dostęp: 8.11.2015].

We wszystkich analizowanych latach wśród ogólnej liczby zdarzeń dominowały zdarzenia meteorologiczne i hydrologiczne. Ich udział nigdy nie spadł poniżej 35\%, a w latach 2012-2014 przekraczał 40\% dla każdej z tych dwóch kategorii (zob. wykres 1). 


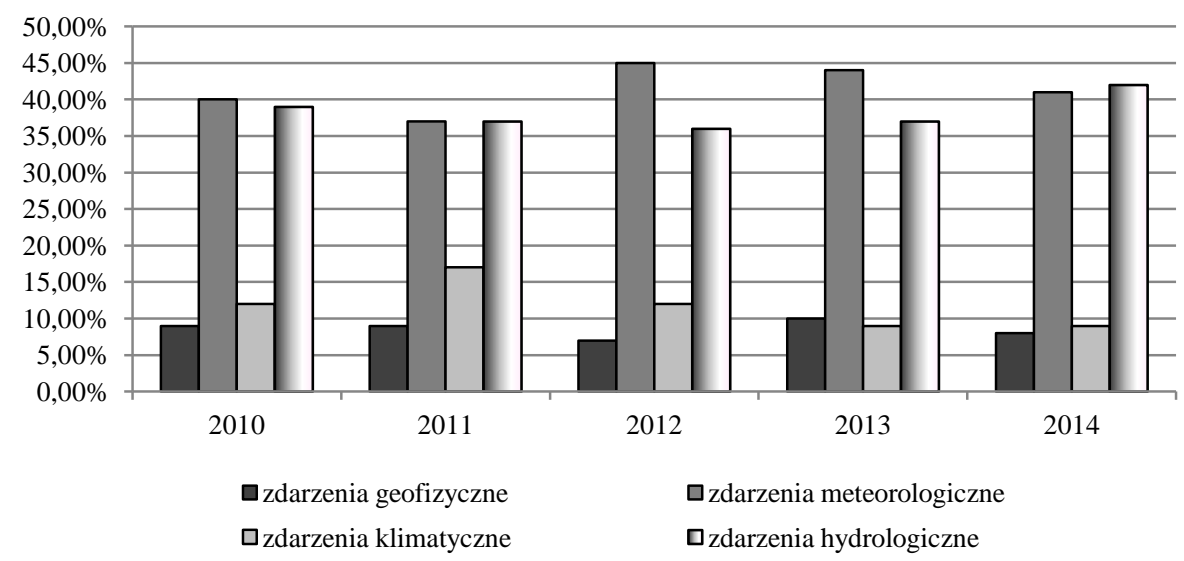

Wykres 1. Katastrofy naturalne na świecie - zdarzenia ogółem w latach 2010-2014 [\%]

Źródło: opracowanie własne na podstawie tab. 1.

Lista trzech największych pod względem strat ogółem katastrof obejmuje w kolejnych latach odpowiednio ${ }^{13}$ :

- 2010 r. - trzęsienie ziemi i tsunami w Chile, powódź w Pakistanie i trzęsienie ziemi na Haiti,

- 2011 r. - trzęsienie ziemi i tsunami w Japonii, powódź w Tajlandii i trzęsienie ziemi w Nowej Zelandii,

- 2012 r. - huragan Sandy na terenie Karaibów i Ameryki Północnej, falę upałów i suszę w Stanach Zjednoczonych i trzęsienie ziemi we Włoszech,

- 2013 r. - powódź w Europie (Austria, Czechy, Niemcy, Polska, Węgry, Szwajcaria), tajfun Haiyan na Filipinach, w Wietnamie, Chinach i na Tajwanie, trzęsienie ziemi w Chinach,

- 2014 r. - cyklon Hudhud i fala sztormowa w Indiach, burze śnieżne w Japonii, powódź w Indiach i Pakistanie.

Lista ta nie pokrywa się z listą zdarzeń, z którymi związane były najwyższe straty ubezpieczone. Nie dotyczy to jedynie kolejności, ale także faktu, że poza pierwszą dziesiątką pod względem strat ubezpieczonych znalazły się dwa kataklizmy związane z ogromną liczbą ofiar śmiertelnych:

- trzęsienie ziemi na Haiti - straty ogółem 8000 mln USD, straty ubezpieczone 200 mln USD, liczba ofiar 222570 ,

- tajfun Haiyan na Filipinach, w Wietnamie, Chinach i na Tajwanie - straty ogółem $10500 \mathrm{mln}$ USD, straty ubezpieczone $700 \mathrm{mln}$ USD, liczba ofiar 6334.

\footnotetext{
${ }^{13}$ https://www.munichre.com/touch/naturalhazards/en/natcatservice/annual-statistics/index.html.
} 
W analizowanym okresie w latach 2010 i 2011 największe śmiertelne żniwo zbierały trzęsienia ziemi, natomiast w latach 2012, 2013 i 2014 najwięcej osób zginęło w wyniku różnego rodzaju zdarzeń hydrologicznych, czyli wielkich powodzi i osunięć ziemi (wykres 2).

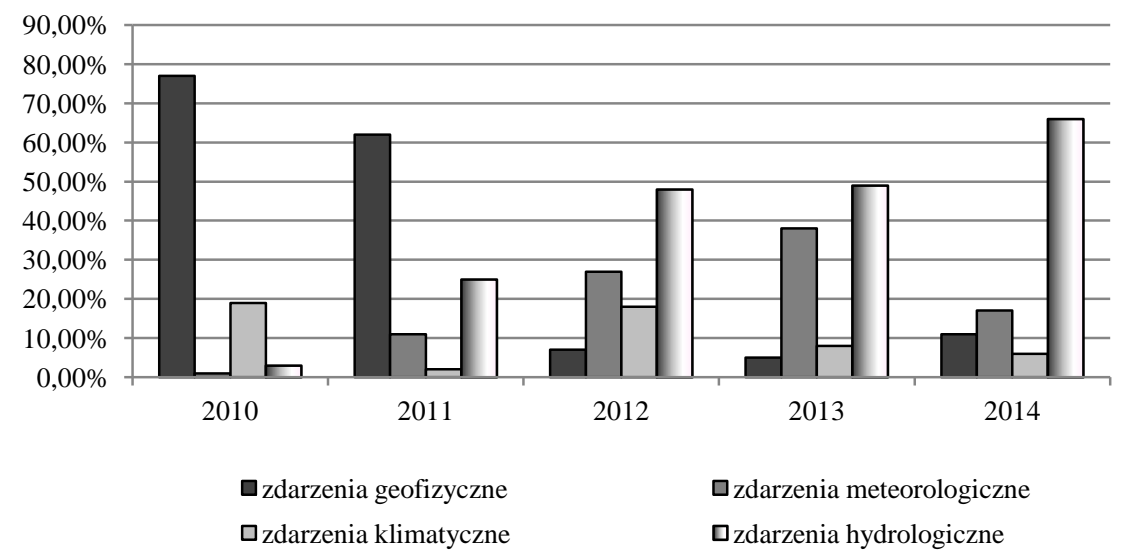

Wykres 2. Ofiary śmiertelne w katastrofach naturalnych na świecie w latach 2010-2014 [\%]

Źródło: jak do wykresu 1.

W analizowanym okresie, w latach 2010 i 2011, przyczyną największych strat poniesionych $\mathrm{w}$ wyniku katastrof naturalnych były trzęsienia ziemi. W pozostałych latach dominowały zdarzenia meteorologiczne i hydrologiczne, których łączny udział wynosił od 72 do $86 \%$ (zob. wykres 3 ).

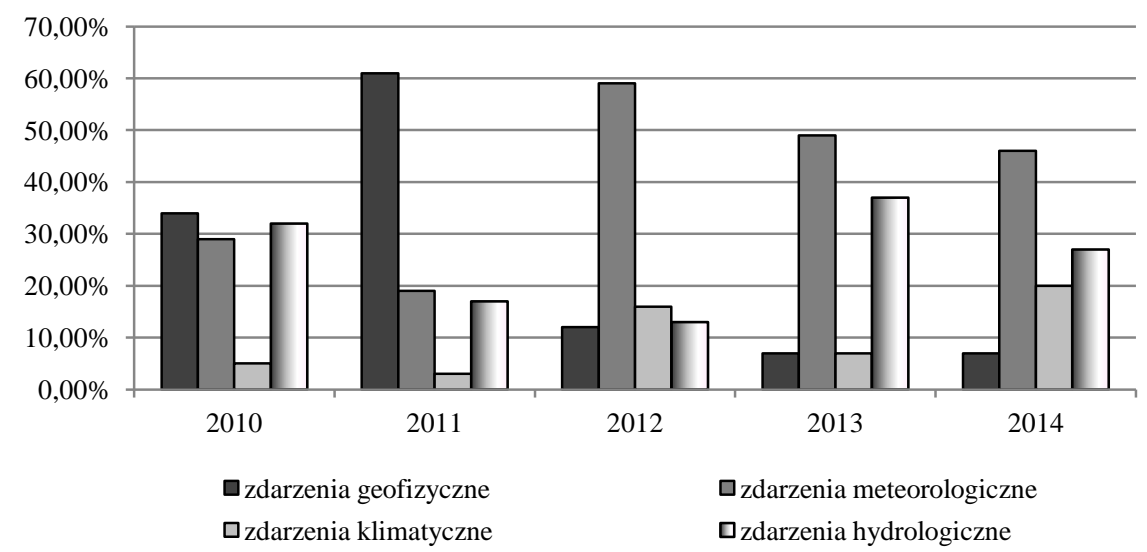

Wykres 3. Katastrofy naturalne na świecie - straty ogółem w latach 2010-2014 [\%] Źródło: jak do wykresu 1. 
W latach 2010-2014 przyczyną największych ubezpieczonych strat poniesionych w wyniku katastrof naturalnych były zdarzenia meteorologiczne, których udział $w$ wypłatach odszkodowań w trzech kolejnych latach 2012, 2013 i 2014 oscylował wokół 70\%. W 2010 r. w pierwszej dziesiątce największych katastrof znalazły się aż trzy trzęsienia ziemi, w tym to najbardziej tragiczne w skutkach na Haiti, ale nawet wtedy zdarzenia meteorologiczne zdominowały straty ubezpieczone. Wyjątkiem jest rok 2011, w którym miały miejsce trzęsienia ziemi $\mathrm{w}$ Japonii i Nowej Zelandii. Kraje te $\mathrm{z}$ uwagi na przynależność do państw wysoko rozwiniętych cechuje wysoki odsetek strat ubezpieczonych. W tym samym roku udział zdarzeń meteorologicznych w stratach ubezpieczonych także był wysoki i wyniósł 37\% (zob. wykres 4).

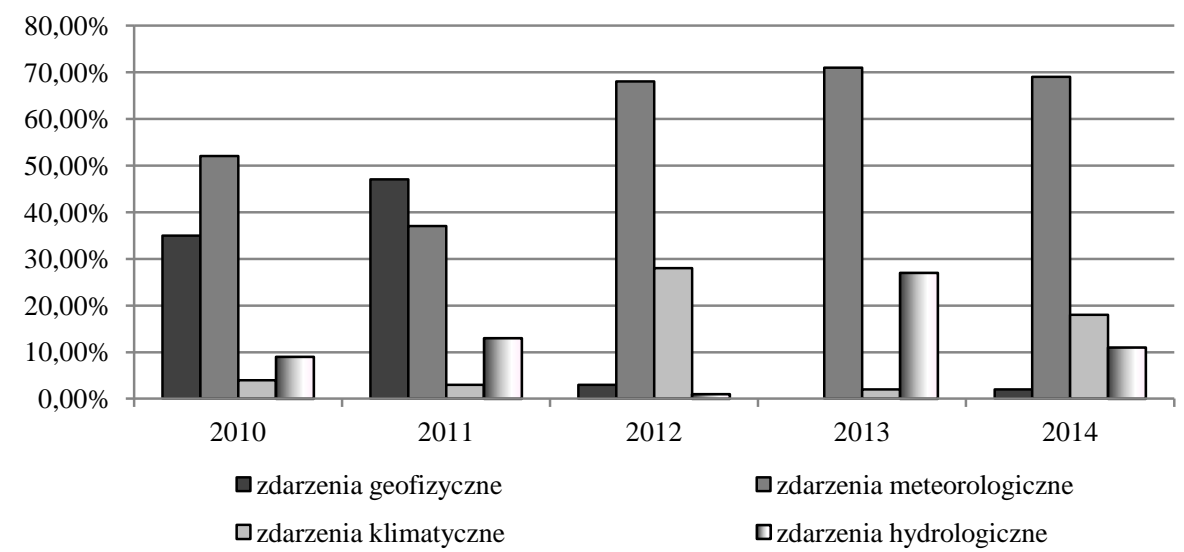

Wykres 4. Katastrofy naturalne na świecie - straty ubezpieczone w latach 2010-2014 [\%]

Źródło: jak do wykresu 1.

Analiza danych przedstawionych w tab. 2 pozwala stwierdzić, że obszarami dotkniętymi największą liczbą katastrof naturalnych była Ameryka Północna i Środkowa wraz z Karaibami oraz Azja. Jeśli chodzi o straty ubezpieczone to udział Azji jest niewielki i na ogół wynosi kilka procent za wyjątkiem lat 2011 i 2014, kiedy żywioły pustoszyły Japonię. Straty ubezpieczone w Afryce stanowią mniej niż $1 \%$ ogółu tych strat na świecie.

Obserwowane nasilanie się ekstremalnych zjawisk pogodowych spowodowało, że od 2013 r. Munich Re publikuje dane statystyczne dotyczące właśnie tych zdarzeń. Obejmują one łącznie zdarzenia meteorologiczne, hydrologiczne i klimatyczne. Szczegółowe informacje zawiera tab. 3. 
W 2013 r. straty spowodowane zdarzeniami pogodowymi stanowiły aż $92,5 \%$, a w 2014 r. $88,1 \%$ ogólnej wartości strat związanych z katastrofami naturalnymi na świecie. Ich wartość wynosiła odpowiednio 125 mld USD i 97 mld USD. Straty ubezpieczone stanowiły 28\% i 30,9\% tych kwot.

Tabela 2. Katastrofy naturalne według kontynentów [\%]

\begin{tabular}{|c|c|c|c|c|c|c|c|}
\hline & Kontynent & $\begin{array}{c}\text { Ameryka } \\
\text { Pn., } \\
\text { Ameryka } \\
\text { Środ., } \\
\text { Karaiby }\end{array}$ & $\begin{array}{c}\text { Ameryka } \\
\text { Płd. }\end{array}$ & Europa & Afryka & Azja & $\begin{array}{c}\text { Australia } \\
\text { i } \\
\text { Oceania }\end{array}$ \\
\hline \multirow{4}{*}{2010} & $\overline{I I}$ & 34 & 5 & 12 & 9 & 33 & 7 \\
\hline & II & 76 & 1 & 19 & - & 4 & - \\
\hline & III & 25 & 25 & 15 & - & 24 & 11 \\
\hline & IV & 40 & 21 & 15 & - & 2 & 22 \\
\hline \multirow{4}{*}{2011} & I & 29 & 6 & 19 & 10 & 29 & 7 \\
\hline & II & 4 & 7 & $<1$ & 3 & 5 & $<1$ \\
\hline & III & 22 & $<1$ & 1 & - & 70 & 7 \\
\hline & IV & 37 & - & 2 & - & 44 & 17 \\
\hline \multirow{4}{*}{2012} & I & 26 & 5 & 15 & 11 & 37 & 6 \\
\hline & II & 7 & 5 & 10 & 13 & 64 & 1 \\
\hline & III & 69 & - & 13 & $<1$ & 16 & $<1$ \\
\hline & IV & 92 & - & 5 & - & 2 & 1 \\
\hline \multirow{4}{*}{2013} & I & 25 & 7 & 15 & 8 & 37 & 8 \\
\hline & II & 3 & 2 & 5 & 5 & 85 & $<1$ \\
\hline & III & 28 & 2 & 20 & $<1$ & 48 & 2 \\
\hline & IV & 50 & 1 & 35 & $<1$ & 9 & 5 \\
\hline \multirow{4}{*}{2014} & I & 20 & 9 & 16 & 10 & 37 & 8 \\
\hline & II & 5 & 5 & 4 & 10 & 75 & 1 \\
\hline & III & 29 & 7 & 16 & 1 & 46 & 1 \\
\hline & IV & 58 & 1 & 21 & $<1$ & 17 & 3 \\
\hline
\end{tabular}

I - zdarzenia katastroficzne ogółem, II - ofiary śmiertelne, III - straty ogółem, IV - straty ubezpieczone.

Źródło: jak do tab. 1 [dostęp: 10.11.2015]. 
Tabela 3. Straty spowodowane zdarzeniami pogodowymi na świecie w latach 2013-2014 [\%]

\begin{tabular}{|c|c|c|c|}
\hline & & 2013 & 2014 \\
\hline \multirow{4}{*}{$\begin{array}{l}\stackrel{\mathscr{Z}}{\bar{N}} \\
\stackrel{\mathbb{Z}}{0} \\
\text { N }\end{array}$} & liczba ogółem & 790 & 900 \\
\hline & z. meteorologiczne & $49 \%$ & $44 \%$ \\
\hline & z. hydrologiczne & $41 \%$ & $46 \%$ \\
\hline & z. klimatyczne & $10 \%$ & $10 \%$ \\
\hline \multirow{4}{*}{ 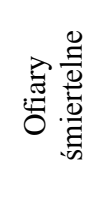 } & liczba ogółem & 19500 & 6900 \\
\hline & z. meteorologiczne & $40 \%$ & $20 \%$ \\
\hline & z. hydrologiczne & $52 \%$ & $73 \%$ \\
\hline & z. klimatyczne & $8 \%$ & $7 \%$ \\
\hline \multirow{4}{*}{ 胥 } & wartość ogółem & 125 mld USD & 97 mld USD \\
\hline & z. meteorologiczne & $53 \%$ & $49 \%$ \\
\hline & z. hydrologiczne & $40 \%$ & $30 \%$ \\
\hline & z. klimatyczne & $7 \%$ & $21 \%$ \\
\hline \multirow{5}{*}{ 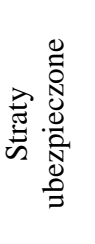 } & wartość ogółem & 35 mld USD & $30 \mathrm{mld}$ USD \\
\hline & jako procent strat całkowitych & 27,3 & 30,9 \\
\hline & z. meteorologiczne & $71 \%$ & $70 \%$ \\
\hline & z. hydrologiczne & $27 \%$ & $12 \%$ \\
\hline & z. klimatyczne & $2 \%$ & $18 \%$ \\
\hline
\end{tabular}

Źródło: jak do tab. 1 [dostęp: 11.11.2015].

Z cytowanych danych statystycznych wyłania się obraz upoważniający do sformułowania wniosku o znaczącym udziale strat wywołanych zjawiskami pogodowymi wśród katastrof naturalnych. Jednocześnie zwraca uwagę stosunkowo niski udział strat ubezpieczonych i ich skoncentrowanie na terenie państw wysoko rozwiniętych. Biorąc pod uwagę prognozy sporządzone przez IPCC, WHO i WMO należy liczyć się z dalszym wzrostem ryzyka występowania ekstremalnych zjawisk pogodowych i jednocześnie wzrostem ryzyka dla zdrowia i życia mieszkańców szczególnie narażonych terenów ${ }^{14}$. Stwarza to nowe wyzwania dla sektora ubezpieczeń zarówno gospodarczych (majątkowych) jak i zdrowotnych.

${ }^{14}$ A. J. McMichael i in., Climate Change and Human Health. Risks and Responses, WHO, Geneva 2003. 


\section{ETYKA W SFERZE UBEZPIECZEŃ OD RYZYK ZWIĄZANYCH ZE ZMIANAMI KLIMATU I EKSTREMALNYMI ZJAWISKAMI POGODOWYMI}

Instytucje ubezpieczeniowe to jedne z najstarszych organizacji finansowych powstałe w odpowiedzi na występowanie ryzyka w życiu człowieka i jego działalności gospodarczej ${ }^{15}$. Przyczyną ich zakładania było dążenie do ograniczenia skutków niekorzystnych zdarzeń losowych spowodowanych siłami natury bądź w wyniku działalności człowieka. Ubezpieczenia są konstrukcją finansową polegającą na tym, że ubezpieczający zasilają fundusz wspólnego ryzyka, a ci którzy ponieśli szkody, otrzymują kompensaty skutków tych szkód od ubezpieczyciela $^{16}$. Innymi słowy ma miejsce dzielenie się ryzykiem i jego transfer. W prawnej systematyce ryzyka rozróżnia się ryzyka osobowe i majątkowe. Ryzyko osobowe powoduje stratę w dobrach osobistych. Może to być przykładowo nieszczęśliwy wypadek powodujący utratę możliwości zarobkowania. Natomiast zniszczenie domu $\mathrm{w}$ skutek powodzi jest związane $\mathrm{z}$ wystąpieniem ryzyka majątkowego.

W przypadku ubezpieczeń gospodarczych kluczową zasadą jest pokrycie strat i szkód powstałych w wyniku nieszczęśliwych zdarzeń losowych i zapewnienie środków na odbudowę majątku. Realizacja ubezpieczenia następuje przez wypłatę odszkodowań i świadczeń z funduszu tworzonego ze składek osób ubezpieczonych.

W przypadku ubezpieczeń ludności wyróżnia się:

- dobrowolne ubezpieczenia majątkowe,

- dobrowolne ubezpieczenia osobowe - np. od następstw nieszczęśliwych wypadków,

- ubezpieczenia obowiązkowe - np. pojazdów samochodowych i następstw nieszczęśliwych wypadków.

Szczególną kategorię ubezpieczeń stanowią ubezpieczenia zdrowotne. W ich przypadku osobie ubezpieczonej przysługują świadczenia zdrowotne mające na celu zachowanie zdrowia, ochronę przed skutkami chorób oraz leczenie. Ubezpieczony w zamian za wnoszoną składkę ubezpieczeniową otrzymuje bezpłatny lub częściowo refundowany przez zakład ubezpieczeń dostęp do placówek medycznych i określonych usług medycznych w zależności od oferowanego zakresu ubezpieczenia. Ubezpieczenia medyczne mogą być obowiązkowe lub dobrowolne (prywatne) ${ }^{17}$. Towarzystwa ubezpieczeniowe oferujące prywatne ubezpieczenia zdrowotne muszą bardzo starannie kalkulować ryzyko choroby

15 S. Owsiak, Finanse publiczne. Finanse ubezpieczeń społecznych. Obowiazki państwa w zakresie ubezpieczeń, Wydawnictwo Naukowe PWN, Warszawa 1999, s. 136.

${ }^{16}$ J. Handschke, J. Monkiewicz (red.), Ubezpieczenia. Podręcznik akademicki, Poltex, Warszawa 2010.

${ }^{17}$ M. Iwanicz-Drozdowska (red.), Ubezpieczenia, PWE, Warszawa 2013. 
swoich ubezpieczonych, aby korzyści ze składek przewyższały koszty świadczeń. Dlatego w bardzo ograniczonym zakresie oferują ubezpieczenia osób starszych, chronicznie chorych lub z wadami wrodzonymi. Działając zgodnie z zasadą opłacalności ekonomicznej wpływają na ograniczenie korzystania ze świadczeń. Z kolei ubezpieczenia obowiązkowe generalnie prowadzą do nadkonsumpcji świadczeń, gdyż ani lekarz (strona podażowa), ani pacjent (strona popytowa) nie są zainteresowani ograniczaniem świadczeń. Rozwiązaniem może być wprowadzenie tzw. strony trzeciej - czyli płatnika, którym jest albo towarzystwo ubezpieczeniowe, albo fundusz środków publicznych ${ }^{18}$. Mogą one pełnić rolę ,strażnika” poprzez wprowadzenie wyceny świadczeń. Wzrost ryzyka występowania chorób przenoszonych przez wektory, jak i konieczność niesienia pomocy medycznej ofiarom klęsk żywiołowych, stanowią poważne wyzwanie dla sektora ubezpieczeń zdrowotnych.

Zmiany klimatu i ekstremalne zjawiska pogodowe są przyczyną zwiększenia ryzyka we wszystkich wymienionych kategoriach ubezpieczeń. Problem ryzyka związanego $z$ katastrofami naturalnymi po raz pierwszy na forum międzynarodowym dostrzeżono pod koniec lat 70. XX w., kiedy opublikowany został raport grupy ekspertów zatytułowany Zagrożenia naturalne $i$ analiza podatności, w którym określono definicję i koncepcję zarządzania ryzykiem, metody służące poprawie rozumienia problemu oraz współpracy między naukowcami, planistami i administracją publiczną. Wskazano także konieczność dalszego rozwoju techniki analizy podatności i zarządzania ryzykiem. Rozdział V poświęcono zjawiskom meteorologicznym i hydrologicznym (tropikalnym cyklonom, tornadom, powodziom rzecznym, falom sztormowym, lawinom i osunię(iom ziemi) $)^{19}$.

Do tej pory pod auspicjami ONZ zorganizowano trzy międzynarodowe konferencje poświęcone zapobieganiu i ograniczaniu skutków katastrof: w 1994. r. w Yokohamie, w 2005 r. w Kobe, w 2015 r. w Sendai ${ }^{20}$. Ryzyka i zarządzanie nimi w warunkach katastrof naturalnych znalazły swoje odzwierciedlenie w przyjętych wówczas dokumentach: Yokohama Strategy, Hyogo Declaration, Hyogo Framework for Action 2005-2015: Building the Resilience of Nations and Communities to Disasters, Sendai Declaration i Sendai Framework for Disaster Risk Reduction 2015-2030.

Wskazano w nich konieczność wymiany doświadczeń związanych z zapobieganiem i ograniczaniem skutków katastrof, stymulacji wzrostu świadomości społeczności i wdrażania polityki informacyjnej służącej ograniczaniu skutków

${ }^{18}$ S. Golinowska, Polityka społeczna państwa w gospodarce rynkowej. Studium ekonomiczne, Wydawnictwo Naukowe PWN, Warszawa 1994, s. 94-97.

${ }^{19}$ Natural Disasters and Vulnerability Analysis, Office of the United Nations Disaster Relief Co-ordinator (UNDRO) 1979, http://www.preventionweb.net/files/resolutions/NL800388.pdf [dostęp: 13.11.2015].

${ }^{20}$ World Conference on Disaster Reduction (WCDR). 
katastrof w regionach zagrożeń, określenia celów i priorytetów działań na szczeblu międzynarodowym, regionalnym, narodowym i lokalnym. Plan działania z. Hyogo: Budowanie odporności krajów i społeczności na klęski żywiołowe był 10-letnim planem przyjętym przez 168 państw członkowskich ONZ, które dobrowolnie zobowiązały się do realizacji działań w celu tworzenia świata bezpieczniejszego pod względem zagrożeń naturalnych i budowania odporności na klęski żywiołowe. Przyjęty w 2005 r. Plan działania z Hyogo wygasł w 2015 r., i został zastapiony przez Sendai Framework for Disaster Risk Reduction 2015 -2030. Wyznaczone zostały następujące obszary działania:

- zrozumienie ryzyka katastrofy,

- wzmocnienie zarządzania ryzykiem,

- inwestowanie w redukcję ryzyka katastrof w celu zwiększania odporności,

- zwiększenie gotowości do skutecznego reagowania w przypadku katastrof $^{21}$.

W Unii Europejskiej przygotowania do udziału w konferencji w Sendai poprzedziło przyjęcie komunikatu Komisji Europejskiej Plan działania z Hyogo na lata po 2015 r.: Zarzadzanie ryzykiem $w$ celu budowania odporności ${ }^{22}$.

Rosnące ryzyko pogodowe, powszechnie kojarzone ze zmianami klimatu, od szeregu lat pozostaje w centrum zainteresowania branży ubezpieczeniowej. Sto dwadzieścia dziewięć firm ubezpieczeniowych z 29 krajów współpracuje ze sobą współfinansując badania nad ryzkiem pogodowym, rozwojem przyjaznych dla klientów dóbr i usług, zwiększaniem świadomości społeczeństwa, włączaniem ryzyka pogodowego do procesu decyzyjnego inwestorów, budowaniem zainteresowania problemem sfery polityki ${ }^{23}$.

Zwykle wielkie katastrofy naturalne będące swoistym sprawdzianem wydolności i skuteczności działania sektora ubezpieczeń ożywiają dyskusję na temat zasad dostępu do ubezpieczeń, cen polis i kosztów funkcjonowania systemu. Ostatnim takim zdarzeniem w najnowszej historii był huragan Katrina, który od swych narodzin 23 sierpnia 2005 r. na Bahamach rozpoczął niszczycielską wędrówkę nad Zatoką Meksykańską, Kubą, Florydą, by jako huragan piątej kategorii wedrzeć się na teren Luizjany, spustoszyć niemal doszczętnie Nowy Orlean, już ze zmniejszoną mocą przemieścić się nad Missisipi i zakończyć żywot na wschodnich wybrzeżach Kanady. Zginęło 1836 osób, 705 uznano za zaginio$\mathrm{ne}^{24}$. Straty tylko w samym Nowym Orleanie, który stał się symbolem niszczycielskiej siły Katriny, oszacowano na 81 mld USD.

${ }^{21}$ Hyogo Framework for Action 2005-2015: Building the Resilience of Nations and Communities to Disasters, www.unisdr.org/wcdr [dostęp: 15.11.2015].

${ }^{22}$ Plan działania z Hyogo na lata po $2015 \mathrm{r}$...

${ }^{23}$ E. Mills, op.cit., s. 1424.

${ }^{24}$ Perspectives: Hurricane Katrina. Analysis of the Impact on the Insurance Industry, Towers Watson 2005. 
Równocześnie ze wzmożoną dyskusją nad wydolnością organizacyjną i finansową dotychczasowych systemów ubezpieczeń od ryzyk katastroficznych warto zwrócić uwagę na problemy etyczne wyłaniające się z rosnącym natężeniem wraz ze wzrostem ryzyk klimatycznych i pogodowych. Należą do nich: nych,

- wykluczenie z systemów ubezpieczeń niektórych osób lub grup społecz-

- nieubezpieczalność niektórych rodzajów ryzyka na pewnych obszarach,

- etos efektywności.

Ze względu na bardzo niski status materialny niektórych osób i grup społecznych nie stać na przystąpienie do jakichkolwiek systemów ubezpieczeń zarówno zdrowotnych, jak i gospodarczych. W krajach słabo rozwiniętych systemy takie najczęściej nie są dostatecznie rozwinięte, by oferować odpowiednie produkty lokalnym podmiotom, a ludność zbyt biedna, by płacić jakiekolwiek składki. Problem w pewnym stopniu dotyczy także krajów bogatych, np. Stanów Zjednoczonych, w których poziom życia, zwłaszcza ludności afro amerykańskiej, daleko odbiega od średniego poziomu dla państwa. W całej rozciągłości było to widoczne w Nowym Orleanie po przejściu Katriny. Stan Luizjana jeszcze przed kataklizmem należał do regionów z najwyższą stopą bezrobocia, niskim poziomem życia i wysoką stopą umieralności niemowląt i dzieci do lat 5, zwłaszcza wśród Afroamerykanów. W Nowym Orleanie zniszczeniu uległo 130000 obiektów mieszkalnych, co stanowiło $70 \%$ budynków ${ }^{25}$. Liczba mieszkańców z 484674 w kwietniu 2000 r. spadła do 230172 w lipcu 2006 r. (w 2014 r. wynosiła 384 320). Niszczycielska siła związana była z jednej strony z oddziaływaniem bardzo silnego wiatru, $z$ drugiej zaś fali powodziowej, która wtargnęła $\mathrm{z}$ morza daleko $\mathrm{w}$ głąb lądu przerywając wały ochronne. Na tle tego podwójnego niszczycielskiego oddziaływania pojawił się dylemat, z jakiego tytułu mają być wypłacane odszkodowania. Otóż typowe polisy ubezpieczeniowe obejmują ubezpieczenie na wypadek huraganowych wiatrów, natomiast nie uwzględniają ryzyka powodzi. W takiej sytuacji towarzystwa ubezpieczeniowe starały się ustalić, w jakiej części zniszczenia spowodował wiatr, co było przedmiotem ubezpieczenia, a w jakiej fala powodziowa, co nie podlegało ubezpieczeniu. $\mathrm{Z}$ punktu widzenia właścicieli były to rozstrzygnięcia kuriozalne, gdyż ich domy zostały najczęściej całkowicie zmiecione z powierzchni ziemi.

Znacząco pogorszyła się także możliwość ubezpieczania dużych obiektów i rezydencji, gdyż wspierający system ubezpieczeń prywatnych federalny program ubezpieczeń od powodzi pokrywa tylko straty do wysokości 250000 USD. $\mathrm{Z}$ uwagi na nową ocenę ryzyka pojawiają się trudności w ubezpieczeniu domów na zagrożonych obszarach. Posiadanie stosownych polis jest często warunkiem stawianym przez kredytodawców hipotecznych, co oznacza, że w wielu przy-

\footnotetext{
${ }^{25}$ http://edition.cnn.com/2013/08/23/us/hurricane-katrina-statistics-fast-facts/ [dostęp: 15.11.2015].
} 
padkach może pojawić się problem z dostępem do odpowiedniego ubezpieczenia już istniejących nieruchomości lub bardzo wysoki wzrost cen polis ${ }^{26}$.

Poważnym zagrożeniem dla życia są też fale upałów. Przykładowo w czerwcu 2015 r. w Indiach temperatury w niektórych regionach dochodziły w cieniu do $47,8^{\circ} \mathrm{C}$, a w Pakistanie do $49^{\circ} \mathrm{C}$ i przyczyniły się do śmierci ponad 4500 osób. Państwowa pomoc doraźna okazała się dalece niewystarczająca i nie była w stanie dotrzeć do wielu miejsc, zwłaszcza w regionach wiejskich.

Wszystkie zagrożenia dla zdrowia są dodatkowo uwarunkowane przez takie czynniki jak status społeczno-ekonomiczny, wiek, płeć, pochodzenie etniczne, czy niepełnosprawność. Zdaniem ekspertów z WHO istnieją mocne dowody na to, że zmiany klimatyczne wpływają niewspółmiernie silnie na zdrowie biedniejszej części populacji a także dzieci i osób starszych. W niektórych sytuacjach różnice dotyczą też kobiet i mężczyzn. Ogólnie rzecz biorąc, zmiany klimatyczne prawdopodobnie przyczynią się do rozszerzenia istniejących nierówności zdrowotnych, zarówno pomiędzy i wewnątrz populacji. Ochrona zdrowia przed zagrożeniami klimatycznymi może być wzmocniona poprzez zapewnienie lepszego i bardziej sprawiedliwego dostępu do podstawowej opieki medycznej, a także podjęcie działań adaptacyjnych do zmian klimatu obejmujących zapewnienie powszechnego dostępu do odpowiedniej infrastruktury w miejscach publicznych.

Wobec narastania zagrożeń związanych z ekstremalnymi zjawiskami pogodowymi coraz bardziej rosną straty towarzystw ubezpieczeniowych i reasekuracyjnych. Ma to wpływ zarówno na ich kondycję finansową i zyski akcjonariuszy, jak i płynność finansową. W wielu przypadkach oddziałuje szerzej także na systemy emerytalne, gdyż towarzystwa emerytalne w przeszłości chętnie inwestowały w akcje firm ubezpieczeniowych. Jak słusznie zauważył P. H. Dembiński w odniesieniu do sektora finansowego „etos efektywności przezwyciężył większość oporów moralnych i stał się ostatecznym kryterium osądów"27.

Omówione trzy kategorie problemów etycznych związanych z funkcjonowaniem systemów ubezpieczeń od ryzyk klimatycznych i pogodowych można sprowadzić do dylematu, jak pogodzić dążenie do osiągania celów ekonomicznych z kryteriami sprawiedliwości i solidarności społecznej. Jak słusznie zauważył W. Sztombka „W centrum zainteresowania etyki życia gospodarczego znajduje się niewątpliwie sprawiedliwość dystrybutywna, określająca zasady rządzące podziałem dóbr dostępnych w społeczeństwie. Kryteria sprawiedliwości dystrybutywnej decydują o tym, jak powinny zostać rozdzielone korzyści i obciążenia, płynące z międzyludzkiej współpracy”. Sprawiedliwość jako pojęcie „rozumu praktycznego" opiera się na zasadach związanych ,z porządkiem roszczeń i uprawnień, zakorzenionych w egoistycznie rozumianych interesach człowieka.

${ }^{26}$ Perspectives: Hurricane Katrina..., s. 11.

${ }^{27}$ P. H. Dembiński, Etyka w sferze finansów, [w:] W. Gasparski (red.), Biznes, etyka, odpowiedzialność, Wydawnictwo Profesjonalne PWN, Warszawa 2013, s. 190. 
Świadomość niesprawiedliwości (...) zbliża ludzi do siebie dopiero wtedy, gdy jest związana $z$ doświadczeniem solidarności"28. Kwestie te w całej rozciągłości dotyczą ludzkiej odpowiedzialności za konsekwencje zmiany klimatu i występowanie ekstremalnych zjawisk pogodowych. Jak sprawiedliwie rozłożyć obciążenia związane z ich skutkami powinno stanowić wyzwanie nie tylko dla systemów ubezpieczeń, ale dla ludzkiej społeczności, która powinna solidarnie stawić im czoła. Efekty dotychczasowych starań nie pozwalają na sformułowanie optymistycznych wniosków co do ich skuteczności. Widoczny jest brak szerszego zrozumienia dla konieczności intensyfikacji międzynarodowej współpracy w dziedzinie adaptacji do zmian klimatu także w odniesieniu do systemów ubezpieczeń. Doraźnie świadczona pomoc humanitarna nie jest w stanie wypełnić istniejącej na polu luki.

\section{PODSUMOWANIE}

Sektor ubezpieczeń jest swoistą światową izbą rozrachunkową dla zagrożeń klimatycznych i pogodowych, które mają wpływ na niemal każdą dziedzinę życia społecznego i gospodarczego. W skali globu przestrzenny rozkład ryzyk związanych z katastrofami hydrometeorologicznymi jest bardzo nierównomierny i wynika zarówno z uwarunkowań naturalnych, jak i gęstości sieci osadniczej i intensywności działalności gospodarczej. W sytuacji oceny, że ryzyka te wykazują tendencję rosnącą, ubezpieczyciele reagują ograniczaniem dostępności polis dla niektórych rodzajów działalności i lokalizacji. Oznacza to, że klienci towarzystw ubezpieczeniowych muszą liczyć się z brakiem możliwości ubezpieczenia i/lub wzrostem cen polis. Grozi to rozrastaniem się grupy osób i podmiotów gospodarczych wykluczonych z systemu ubezpieczeń od ryzyk pogodowych. Ponadto istniejące rynki nie zapewniają sprawiedliwego i solidarnego rozwiązania problemu. Podejmowane próby przerzucenia mostu między etyką a ekonomią $\mathrm{w}$ odniesieniu do sektora ubezpieczeń napotykają na poważne przeszkody związane z trudnościami w kalkulacji ryzyka katastroficznych zdarzeń hydrometeorologicznych $\mathrm{z}$ jednej strony i jego pieniężnej wyceny $\mathrm{z}$ drugiej. Kwestie etyczne pozostają na marginesie współczesnej dyskusji nad funkcjonowaniem systemu ubezpieczeń od ryzyk klimatycznych i pogodowych.

${ }^{28}$ W. Sztombka, Etyka gospodarcza wobec dylematów sprawiedliwości i solidarności, „Annales. Etyka w Życiu Gospodarczym” 1999, vol. 1, Salezjańska Wyższa Szkoła Ekonomii i Zarządzania, s. 34-35. 


\section{BIBLIOGRAFIA}

Botkin i in., Oblicza ziemi - zagrożenia i nadzieje, Raport The Smithonian Institution i National Geographic, 2001.

Burchard-Dziubińska M., Instytucjonalne aspekty międzynarodowej wspótpracy $w$ dziedzinie ochrony środowiska przyrodniczego, Wydawnictwo Uniwersytetu Łódzkiego, Łódź 2006.

Conference Report, Conference on Health and Climate Change, Word Health Organization, 27-29 August 2014, Geneva Switzerland, http://www.who.int/globalchange/mediacentre/ events/climate-health-conference/whoconference-onhealthandclimatechangefinalreport.pdf.

Dembiński P.H., Etyka w sferze finansów, [w:] W. Gasparski (red.), Biznes, etyka, odpowiedzialność, Wydawnictwo Profesjonalne PWN, Warszawa 2013.

Golinowska S., Polityka społeczna państwa w gospodarce rynkowej. Studium ekonomiczne, Wydawnictwo Naukowe PWN, Warszawa 1994.

Handschke J., Monkiewicz J., (red.), Ubezpieczenia. Podręcznik akademicki, Poltex, Warszawa 2010.

Hyogo Framework for Action 2005-2015: Building the Resilience of Nations and Communities to Disasters, www.unisdr.org/wcdr.

Iwanicz-Drozdowska M., (red.), Ubezpieczenia, PWE, Warszawa 2013.

Liszka S., Pasierb S., Energetyka a zmiana klimatu, Instytut na rzecz Ekorozwoju, Warszawa 2008.

McMichael A. J. i in., Climate Change and Human Health. Risks and Responses, WHO, Geneva 2003.

Mills E., The Greening of Insurance, „Science”, 14 December 2012, vol. 338(1425), www.sciencemag.org [dostęp: 15.11.2015].

Natural Disasters and Vulnerability Analysis, Office of the United Nations Disaster Relief Co-ordinator (UNDRO) 1979, http://www.preventionweb.net/files/resolutions/NL800388.pdf.

Owsiak S., Finanse publiczne. Finanse ubezpieczeń spotecznych. Obowiązki państwa $w$ zakresie ubezpieczeń, Wydawnictwo Naukowe PWN, Warszawa 1999.

Perspectives: Hurricane Katrina. Analysis of the Impact on the Insurance Industry, Towers Watson 2005.

Plan działania z Hyogo na lata po 2015 r.: Zarzadzanie ryzykiem w celu budowania odporności, Komunikat Komisji do Parlamentu Europejskiego i Rady, Europejskiego Komitetu Ekonomiczno Społecznego i Komitetu Regionów, Bruksela, 8 kwietnia 2014 COM(2014) 216 final.

Sultana F., Loftus A., Prawo do wody w perspektywie politycznej, gospodarczej i społecznej, PAH, Warszawa 2012.

Sztombka W., Etyka gospodarcza wobec dylematów sprawiedliwości i solidarności, [w:] „Annales. Etyka w Życiu Gospodarczym” 1999, vol. 1, Salezjańska Wyższa Szkoła Ekonomii i Zarządzania.

Ustawa z 18 czerwca 2002 r o stanie klęski żywiołowej, DzU 2002, nr 62, poz. 558.

Wybig J., Wspótczesne zmiany klimatyczne - przesłanki wpływu czynników antropogenicznych, Katedra Meteorologii i Klimatologii Uniwersytetu Łódzkiego, Łódź 2008.

http://edition.cnn.com/2013/08/23/us/hurricane-katrina-statistics-fast-facts/.

http://www.cadrought.com/drought-monitor/.

http://www.ipcc.ch/.

http://www.munichre.com/touch/portal/en/homepage/default-engineering/index.html.

https://www.munichre.com/touch/naturalhazards/en/natcatservice/annual-statistics/index.html. 


\title{
ETHICAL ASPECTS OF INSURANCE SECTOR FUNCTIONING IN CONSIDERATION OF CLIMATE CHANGE AND EXTREME WEATHER PHENOMENA
}

\begin{abstract}
Observed climate change and associated extreme weather phenomena are causes of increasing losses for societies and economies around the world. These are also challenge to insurance sector, which estimated that around $75 \%$ of natural disasters with total value close to USD 100 bn per year, is associated with hydro-meteorological phenomena. In the text ethical aspects of the functioning of insurance sector due to the increased risks of natural disasters are discussed. The main ethical challenges are: exclusion of certain individuals or social groups from insurance system, the lack of insurance possibilities due to the increased risk and ethos of efficiency.

Attempts to built the bridge between ethics and economics in relation to the insurance sector face significant obstacles related to difficulties in calculating the risks of natural catastrophic occurrences on the one hand and its monetary valuation on the other. Ethical issues remain on the margins of contemporary discussion about the insurance against risks of climate change and extreme weather phenomena.
\end{abstract}

Keywords: ethics, insurance sector, climate change, extreme weather phenomena. 